\title{
Departmental Advisory Boards - Their Creation, Operation, and Optimization
}

\author{
Michael B. Cutlip \\ Department of Chemical Engineering, University of Connecticut, Unit 3222, \\ Storrs, CT 06269-3222 Michael.Cutlip@Uconn.Edu
}

Most academic engineering departments should strongly consider having a Departmental Advisory Board. There are many options for the membership, purposes, and usefulness of these Boards. This paper will present the views and suggestions of an engineering faculty member who has been associated with boards for Chemical Engineering Departments - as a faculty member, as a department head, and as a member of a Board at another university. Experiences over a 35-year period will be used to explore ways in which these Boards and their members can be utilized to the fullest advantage for the sponsoring Departments and for the Engineering College.

\section{Introduction}

The following are my personal views on the operations of a Departmental Advisory Board. They are based on career-long experiences with Boards in various capacities. My first contact with a Board was as an assistant/associate professor participating in our department's Board when it was the only one in the engineering college. I then managed and interacted with a Board as a department head for nine years. Finally, I am now a professor who interacts with our current Board, and I am serving my third year as a member of a Board for the department in which I received my $\mathrm{Ph}$. D. some 36 years ago.

All academic departments in engineering disciplines should strongly consider establishing a continuing "Departmental Advisory Board" that meets on an annual basis. Such a Board can have a variety of responsibilities as it provides important advice and guidance for an academic department. The key word in the title of this Board is ADVISORY, and the members may need to be reminded from time to time that all of their advice may not be viewed as appropriate by the department faculty or department chair. In some cases, the advice may not be possible as there are many constraints in the academic world that are just not known or appreciated by those whose careers are beyond the academic ivory towers. But in general, an appropriately organized, charged, and managed Board can be a major asset to a progressive and dynamic department.

\section{Board Membership}

It is very important to organize a Board properly so that it is efficient and effective in carrying out its many activities. New Board members should know the term limits in advance. My experience leads me to suggest that terms of three years are most appropriate, and staggered terms should result in a one-third-turnover per year of Board members. There should be a

Proceeding of the 2003 American Society for Engineering Education Annual Conference \& Exposition Copyright ${ }^{\circ}$ 2003, American Society for Engineering Education 
limitation of at most two consecutive terms for each Board member, but only in special cases. For most members, a single three-year term allows major contributions from the individual Board member without a burdensome commitment of time and effort.

Board members should be carefully selected, based in part on the mission of the Board as viewed by the academic department. In general, the Board should be comprised from among the following types of members with a variety of terminal degree levels and with a good representation of women and minorities:

- Alumni or professionals who work for the federal government outside of state

- Alumni or professionals who work for state agencies with the state

- Alumni or professionals who are established faculty member at other similar institutions

- Alumni or professionals who work for major corporations outside of state

- Alumni or professionals who work for mid-sized corporation within the state

- Alumni who are considering making major gifts or bequests to the department

- Alumni or professionals who work for a local company with strong ties to the department

- Legislators or professionals tied to state government with some status in state funding

- Professionals who work for a company that is a major participant in a research center or institute at the university (These individual may have an important role in the company's research interaction with several faculty members within the department.)

Board membership should be approximately equally divided between alumni of the department and other professionals. A distribution of ages and experience levels is highly desirable. This is particularly true for the alumni as the department may have evolved significantly over the years and many changes may have occurred. Membership should not be limited to individuals with degrees in the discipline of the academic department such as chemical engineering; however, a strong majority of the Board should have a degree at some level in the departmental discipline.

An active or retired academic faculty member is a highly desirable member on the Board as this individual can provide essential input to the Board as to what can and cannot be done or accomplished in academic departments. (This knowledge is not always widely known or appreciated, and this input is always needed, particularly in closed discussions of the Board and during final report preparation.)

My experience has been that mid-level professionals from corporations are very appropriate for membership in departmental committee. Ideally, these individuals can provide input to the company management on those matters that are important to the department and the company. They also may be concurrently participating in activities in which they interact with departmental faculty in areas such as recruiting and cooperative research projects.

Advisory Boards have now evolved so that most Engineering Deans have such a Board. These Board members tend to be higher up in the management ranks within the corporations or other organization that they serve. One the top of this ladder is the Board of Trustees for the institution, which typically is comprised of individuals from the very top management of 
successful major corporations and also includes very wealthy individuals who have been extremely successful and have a capacity to make major contributions to the general institution.

A logical step for some of the departmental Board members would be the progression to the Dean's Advisory Board and possibly to the Board of Trustees for the institution.

\section{Board Size}

My suggestion is the Board should consist of about 10 members with the assumption that 2-3 will not be able to make the meetings. It might be helpful to suggest that some of the members provide alternates should the member not be able to attend a particular meeting. This option should be given to those members who are serving as representatives of their company or governmental agency. Too large a board can discourage active participation while too small a board can place too much work on the various individual members.

\section{Board Meetings}

The department chair should coordinate the oversight of Board membership, meetings, correspondence, and other activities. This is an important duty that cannot be delegated to others as the Board expects direct input and interaction with the department's chair. This is not a minor assignment for the chair, and a new departmental chair should realize that this is an important but time-consuming activity that must be carried out with careful attention to the many details.

Selection of new Board members requires the considered input of departmental faculty, alumni, retiring and former Board members, plus current department contacts. Once the determination of a potential new member is made, the department chair should make the contact directly with the individual while making sure that the terms and the duties are clearly outlined.

Board members should make a commitment to try and attend all of the meetings during their term. All members from corporations or governmental agencies are normally able to pay their own expenses to the meetings; however, the department should offer to pay the costs of any members who are from academia or those who are retired.

Meetings should be scheduled well in advance and annual meetings are the usual norm. Meeting timing can vary, but I suggest approximately the same timing for each year. My preference is for the second half of the academic school year with perhaps a date just before final exams as the optimal time. Our current departmental meeting date is the first "reading day" before final exams start, and this allows student participation for several hours without scheduling difficulties for meeting facilities or for the necessary student and faculty participation. Also, spring in New England is a particularly pleasant time.

Meetings should not exceed 1.5 days in length. For departments where many Board members can easily commute to campus, a one-day meeting may be adequate. For other departments, the 
meeting should be limited to require only two days of time for a board member flying in from a distant location.

The departmental secretary or administrative assistant should offer to coordinate the housing and parking for the attendees. Often, there is a hotel on or near campus where rooms can be made available to Board members.

\section{Meeting Agenda and Activities}

The department chair and Board Chair should set the tentative agenda and distribute this well in advance to the Board members. This should allow for any suggestions from the Board or departmental faculty to be considered. An important item on the agenda should be a review of the previous Board meeting and a report on any action items to the Board by the Department Chair.

\section{Major Theme}

It is very important to have a major theme associated with each Board meeting. Some possible themes include:

- Review of the Undergraduate Program

- Review of the Graduate Program

- Major Research Review Perhaps Limited to Particular Research Areas

- Overview of Major Research Centers or Institutes

- ABET Review Preparation

- Student Recruitment - Graduate and Undergraduate

- Placement of Graduates at All Levels

- Program Review Activities for the Institution

- Major Initiative such as an NSF Research Center Application

- Strategic Planning

- Future Directions for the Departmental Discipline

\section{Continuing Themes}

The Board meeting may be used as an annual forum for the undergraduate students and the graduate students to separately provide input to the department regarding their general programs including suggestions and constructive criticisms for current departmental policies. Student leaders and a cross-section of students should be invited to participate in these forums. The department chair needs to see that this organization is done and that invitations to student participants are made. This annual interaction with students (separately for undergraduate and graduate students) in the absence of faculty provides a useful avenue for general unrestricted student input to reach the faculty of the department.

\section{ABET Assistance}

The Board can be very helpful in ABET matters by conducting a cycle of coursework reviews with a limited number of reviews to be undertaken at each meeting. This can become an 
important part of the continuing assessment needs of the ABET accreditation. A three or four year cycle could have subgroups of the Board review and assess all of the core undergraduate courses as well as the entire curriculum.

\section{Task Force Sessions}

The Board or a subset of Board members, selected faculty members, and student representatives can consider specific important matters. An example here might be a proposed change in the name of the departments in which there are many implications for current operations and future directions of the department.

\section{General Session}

There should be some event during the meeting where the entire departmental faculty is available for informal interactions with the Board. This can be at a general luncheon or at a lengthened coffee break. The latter could occur at the end of a general session during the Board meeting such as a departmental research review in which the faculty is present.

\section{Working Session for Board/Exit Meeting}

A general working meeting of only the Board members should be scheduled as one of the last events of the Board meeting. The members should agree on the general points to be discussed during the exit meeting with the department chair and other departmental administrators such as the directors of the graduate and undergraduate programs.

\section{Operational Chair of the Board Meeting}

An experienced Board member who is identified a year in advance should chair each Board meeting. This Board chair should work with the departmental chair in setting the agenda and oversee the creating of the Board reports as these are expected or needed. Another Board member should be designated as "recorder" and given the responsibility for taking notes and collecting all materials that have been presented to the Board during the meeting.

The Board chair should be the spokesperson for the Board at an exit meeting with the department chair and possibly the directors of graduate and undergraduate studies. This Board chair should also coordinate the overall collection, editing and submission of the annual Board report. This Board chair should be responsible for possible additional interactions with the engineering Dean or other institutional administrators on behalf of the Department Advisory Board when these are desirable during the year following the Board meeting.

\section{Board Reporting}

The Board Char should prepare the annual report of the Board meeting, and a departmental secretary should help to reproduce and distribute the report. Copies should be made available to the Board, the departmental faculty, and other participants. A copy should also be sent to the Dean of Engineering and other institutional officials. 


\section{Board Activities throughout the Year}

While Board activities are normally centered on the annual Board meeting, the Board Chair should be available to represent the Board in important matters arise that need rapid resolution as well as Board input. Institutional proposals or initiatives requiring rapid input include administrative restructuring (departments or research centers) that might directly affect the department. These may need to be addressed in a very timely manner. Here the voice of the Board Chair could be very beneficial to the department in dealing with institutional officials.

Board members who reside locally should also be invited to various events throughout the year such as those that typically honor departmental students, award scholarships, and recognize special achievements within the department and the engineering college.

\section{Conclusions}

Most engineering departments or programs should have a Department Advisory Board. There are a variety of tasks and functions that such a Board can undertake that will greatly benefit the department and more than justify the work and energy required to host such a Board. Many such tasks and functions are identified in this paper, but these activities will vary widely from department to department. Effective Board organization and management will lead to continual improvements in both Engineering education and research productivity within the host department that will positively impact both continuing and future students. The annual Board meeting will also provide a positive feeling of collective community responsibility among the Board members, the departmental faculty and the departmental students for positive contributions to the overall direction and development of the host department.

\section{Biographical Information}

Michael B. Cutlip is professor of chemical engineering at the University of Connecticut in Storrs, CT where he has been on the faculty for 35 years. He has been particularly active with the AICHE and the ASEE Chemical Engineering Division having served as Division Programming Chair for the Seattle Annual Meeting in 1998 and was the Division Chair in 2000. He was also a co-chair of the ASEE Chemical Engineering Division Summer School in 2002 at the University of Colorado. 